\title{
Can biofortification of zinc improve the antioxidant capacity and nutritional quality of beans?
}

\author{
Juan Pedro Sida-Arreola1, Esteban Sánchez*, Dámaris Leopoldina Ojeda-Barrios², \\ Graciela Dolores Ávila-Quezada², María Antonia Flores-Córdova², César Márquez-Quiroz ${ }^{3}$, \\ Pablo Preciado-Rangel ${ }^{4}$
}

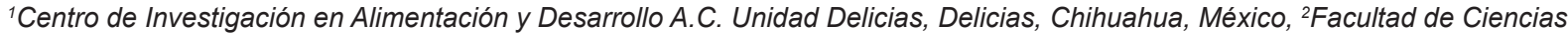
Agrotecnológicas, Universidad Autónoma de Chihuahua, Chihuahua, México, ${ }^{3}$ Universidad Juárez Autónoma de Tabasco, Villahermosa, Tabasco, México, ${ }^{4}$ Instituto Tecnológico de Torreón, Torreón, Coahuila, México

\section{A B S T R A C T}

In this work, it was determined how zinc biofortification improves nutritional quality and antioxidant system of green bean under greenhouse conditions. It was applied two forms of zinc: Sulphate and chelate (ZnSO4 and Zn-DTPA) with four doses (0, 25, 50 and $100 \mu \mathrm{M})$ in a hydroponic system, and were evaluated for 40 days. Nutritional quality and antioxidant capacity was determined in seeds. Results showed that $\mathrm{Zn}$ biofortification improves nutritional quality and antioxidant activity of beans, both attributes of quality and consumer health. Significantly different results on antioxidant capacity were obtained with $25 \mu \mathrm{M}$ of $\mathrm{Zn}$ chelate compared to sulphate, while in bean nutritional quality, both forms ( $\mathrm{Zn}$ chelate and sulfate) had similar results with doses of 25 to $50 \mu \mathrm{M}$. Finally, it is possible to implement a $\mathrm{Zn}$ biofortification program in bean plants, as this nutrient is more concentrated in seeds (edible part of the plant), allowing improve the antioxidant capacity and nutritional quality.

Keywords: Mineral malnutrition; Phaseolus vulgaris; Zinc chelate; Zinc sulfate

\section{INTRODUCTION}

Legumes represent an important group in nutrition in the world, and represent an important source of protein, oil, vitamins, and minerals (Katoch, 2013; Marquez-Quiroz et al., 2015). Common bean is a food crop, which is one of the main protein sources in the developing world and also in minerals, fiber, and phytochemicals with analgesic and neuroprotective properties (Jha et al., 2015). Common bean is a staple crop and also a source for these minerals having more iron (around $55 \mu \mathrm{g} / \mathrm{g}$ ) and zinc (around $35 \mu \mathrm{g} / \mathrm{g}$ ) than cereals (Beebe et al., 2000). It was showed that there is a correlation between $\mathrm{Zn}$ and Fe in bean cultivars (Hoppler et al., 2014).

$\mathrm{Zn}$ is an important micronutrient because it plays important roles in crop production and human nutrition (Broadley et al. 2007). Approximately $10 \%$ of human proteins require $\mathrm{Zn}$ for maintain their catalytic activity (Andreini et al. 2006). $\mathrm{Zn}$ is involved in the biosynthesis of proteins and in scavenging of reactive oxygen species (Cakmak 2000;
Broadley et al. 2007). Zinc is deficient in $30 \%$ of soils used for agriculture in the world (Alloway 2008), and WHO reports that about $33 \%$ of the population is affected by Zn deficiency, which represent 450,000 dead children under five years old every year (Black et al., 2008). Increasing $\mathrm{Zn}$ levels in crops will lead to more $\mathrm{Zn}$ in humans. $\mathrm{Zn}$ application was an effective strategy of biofortification to increase Zn concentration in rice and wheat (Cakmak, 2008, Shivay et al., 2008), but information specific to common bean is limited.

Micronutrient deficiencies in humans can be decreasing by increasing the mineral quality in edible crops. Biofortification is a promising strategy aimed to improving the mineral content of the staple plant food. Agronomic biofortification can improve the nutritional quality in the plant without it suffers genetic modifications (Storksdieck and Hurrell, 2009). Agronomic biofortification define the process of increase the concentration of essential elements in portions of plants through fertilization. This strategy was developed as a food-based method to help to decrease

\footnotetext{
*Corresponding author:

Esteban Sánchez, Centro de Investigación en Alimentación y Desarrollo A.C. Unidad Delicias. Av. Cuarta Sur 3820, Fracc. Vencedores del Desierto. Cd. Delicias, Chihuahua. México, C.P. 33089. E-mail: esteban@ciad.mx
} 
widespread deficiencies in $\mathrm{Fe}$ and $\mathrm{Zn}$ that is prevalent in developing countries (Mao et al., 2014).

Soil and foliar biofortification with $\mathrm{Zn}$ is an effective solution to its deficiency problems in human health and crop production (Cakmak 2008; Prasad et al. 2014). However, there are little information about the way in which $\mathrm{Zn}$ biofortification can influence the quality of nutrients in plants and particularly the antioxidant capacity. Thus, this research was focused in the determination of the effect of $\mathrm{Zn}$ biofortification with two forms of $\mathrm{Zn}$, on the nutritional status and antioxidant activity of common bean as bioindicator of an efficient $\mathrm{Zn}$ biofortification program in bean plants (Phaseolus vulgaris L.).

\section{MATERIALS AND METHODS}

\section{Crop handling}

Bean seeds were germinated in a substrate mix (peat moss, vermiculite and perlite at ratio 3:1:1) and grown in greenhouse conditions in Delicias, Chihuahua, México. Bean seeds were purchased in Agrow Mexico in Mexico City. This variety of beans is a short cycle (sixty days), and it is grown in soils without saline problems and it is suitable to grown in greenhouse. Greenhouse temperature was at $25^{\circ} \mathrm{C} \pm 4^{\circ} \mathrm{C}$, humidity of $60-80 \%$, and a light period of $16 / 8 \mathrm{~h}$ (light/darkness). Plants were grown in pots $(25 \mathrm{~cm}$ diameter) with volume of $8 \mathrm{~L}$, filled with substrate mix. Throughout the growing cycle the bean plants received a growth nutrient solution composed of $6 \mathrm{mM} \mathrm{NH}_{4} \mathrm{NO}_{3}$, $1.6 \mathrm{mM} \mathrm{K}_{2} \mathrm{HPO}_{4}, 2.4 \mathrm{mM} \mathrm{K}_{2} \mathrm{SO}_{4}, 4.0 \mathrm{mM} \mathrm{CaCl}_{2} .2 \mathrm{H}_{2} \mathrm{O}$, $1.4 \mathrm{mM} \mathrm{MgSO}, 5 \mu \mathrm{M}$ Fe-EDDHA, $2 \mu \mathrm{M} \mathrm{MnSO}{ }_{4} \cdot \mathrm{H}_{2} \mathrm{O}$, $1.0 \mu \mathrm{MZnSO}_{4} .7 \mathrm{H}_{2} \mathrm{O}, 0.25 \mu \mathrm{M} \mathrm{CuSO}_{4} .5 \mathrm{H}_{2} \mathrm{O}, 0.3 \mu \mathrm{M}\left(\mathrm{NH}_{4}\right)$ $\mathrm{Mo}_{7} \mathrm{O}_{24} \cdot 4 \mathrm{H}_{2} \mathrm{O}$ and $0.5 \mu \mathrm{M} \mathrm{H}_{3} \mathrm{BO}_{3}$ (pH 5.5- 6.0).

\section{Experimental designs and treatments}

In this research a completely randomized experimental design was used, with two forms of $\mathrm{Zn}, \mathrm{Zn}$-DTPA and $\mathrm{ZnSO}_{4}$ at doses of $0,25,50$ and $100 \mu \mathrm{M}$, respectively, according to Sida-Arreola et al. (2015).

\section{Sampling and plant analysis}

Plants were sampled at 60 days of its germination, at complete phenological phase (development and fruit maturity). Organs of each plant were separated (seed, pod, root, stems, leaf). One part of plant material was frozen using liquid nitrogen and stored at $-30^{\circ} \mathrm{C}$, this material was used for antioxidant capacity assays (DPPH method, Brand-Williams et al., 1995). The other part of plant material was dried at $65^{\circ} \mathrm{C}$ and used to the determination of the nutritional quality (Karacan and Aslantas, 2008) in bean seed.

\section{Determination of the antioxidant capacity (DPPH method)}

The analysis was performed according to Brand-Williams et al.(1995) methodology. $1 \mathrm{~g}$ of seeds was used to macerate it in $5 \mathrm{~mL}$ of $80 \%$ methanol, and centrifuged at $6000 \mathrm{rpm}$ for $10 \mathrm{~min} .0 .5 \mathrm{~mL}$ of the resulting supernatant extract were taken and added to $2.5 \mathrm{~mL}$ of a $0.1 \mathrm{mM} \mathrm{DPPH}$ freshly prepared solution, and mixture was incubated for $60 \mathrm{~min}$ in dark and cooled. It was measured the absorbance spectrophotometrically at $517 \mathrm{~nm}$. White sample extract consisted of $0.5 \mathrm{~mL}$ of methanol. Values obtained by DPPH test were calculated by applying the following formula: $\mathrm{g}^{-1}$ percentage dry weight $=(1$ - (samples A517/A517 white) x 100.

\section{Determination of nutritional quality (macro and micronutrients)}

Determination of $\mathrm{N}, \mathrm{P}, \mathrm{K}, \mathrm{Ca}, \mathrm{Mg}, \mathrm{Fe}, \mathrm{Mn}, \mathrm{Zn}$ and $\mathrm{Cu}$ were made according to Wolf (1982). As $0.2 \mathrm{~g}$ of dry seeds were mineralized in $12 \mathrm{~N} \mathrm{H}_{2} \mathrm{SO}_{4}$ and $30 \% \mathrm{H}_{2} \mathrm{O}_{2}(\mathrm{v} / \mathrm{v})$ free $\mathrm{P}$ at $275-300^{\circ} \mathrm{C}$. The result of mineralization was gauged with $50 \mathrm{~mL}$ deionized water. The total $\mathrm{N}$ concentration was determined based on the Berthelot reaction method with modifications. Total $\mathrm{P}$ content was determined using the nitrovanadomolibdate colorimetric method. Total concentration of $\mathrm{K}, \mathrm{Ca}, \mathrm{Mg}, \mathrm{Fe}, \mathrm{Mn}, \mathrm{Cu}$ and $\mathrm{Zn}$ were quantified by atomic absorption spectrometry.

\section{Statistical analysis}

It was used a simple ANOVA at 95\% confidence, using SAS (SAS Institute Inc., Cary, USA). Means were compared by the Tukey's test $(\mathrm{P} \leq 0.05)$. The data shown are mean values \pm standard error $(\mathrm{SE})$.

\section{RESULTS AND DISCUSSION}

\section{Antioxidant capacity}

Antioxidants are compounds found in food and have positive health effects because of its potential to protect humans against reactive oxygen species (Padilla et al., 2008). In our study, we found significant differences in antioxidant capacity (DPPH method) as a result of the application forms and rate of $\mathrm{Zn}$ (Fig. 1), where generally the chelate $\mathrm{Zn}$ was better to $\mathrm{Zn}$ Sulfate to the dose of $25 \mu \mathrm{M}$, indicating that this form of $\mathrm{Zn}$ improves one of the attributes of bean quality and consumer health. Yuan et al. (2016) studied the result of enrichment of zinc on antioxidant capacity and growth in pea sprouts and found an increase from 10 to $50 \mu \mathrm{M}$ Zinc improved antioxidant capacity due in turn to increase the $\mathrm{Zn}$ content, chlorophylls, phenolic content and amino acids, $\mathrm{Zn}$ enrichment could increase the nutritional quality and antioxidant activity as functional foods. Previous studies 
showed that the antioxidant capacity may depend on the abundance of metal ions (Zhu et al. 2013). This means that certain metals are required in small quantities by humans and they act as cofactors of enzymes, transcription factors and signaling proteins. These include various enzymes with the function of remove reactive oxygen species, in which the metals are used as cofactors of antioxidant enzymes, like various forms of superoxide dismutase (requires $\mathrm{Cu}, \mathrm{Mn}$ and/or Zn; Johnson and Giulivi, 2005), catalase (requires $\mathrm{Fe}$ ) and glutathione peroxidase (requires selenium) (Mates et al., 1999). Ríos et al. (2008) conducted a study with Se biofortification in lettuce and they observed that the treatment with $40 \mu \mathrm{M}$ selenate was the most adequate for lettuce plants, improving the antioxidant activity and accumulation of selenium, which is important in food and consumer health. Likewise, Blasco et al. (2008) mentions that biofortified lettuce plants with iodine at a dose of 40 $\mu \mathrm{M}$ under the form of I- improved biomass, antioxidant activity and mineral content of lettuce, ensuring the viability of a program biofortification.

\section{Nutritional quality}

Nutritional quality is one important topic to consider when talking about food, because they determine the functionality

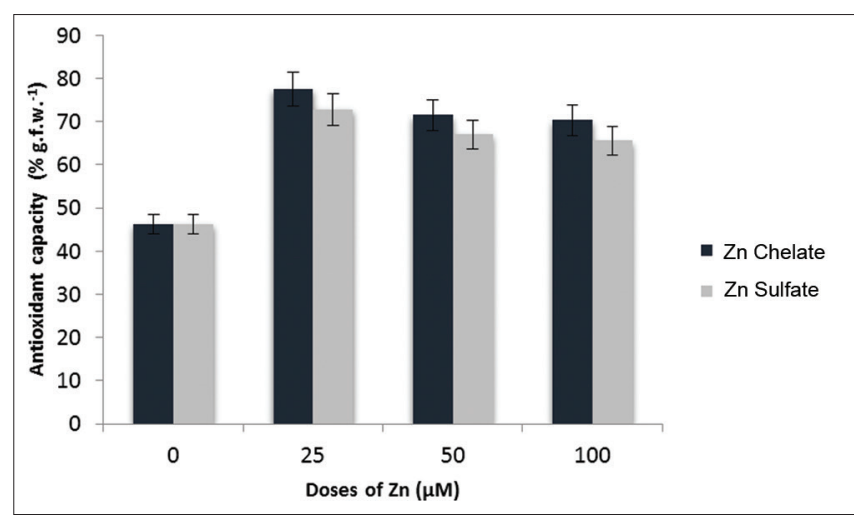

Fig 1. Antioxidant capacity (DPPH) in bean seeds under different doses of sulfate and zinc chelate. Data are means \pm standard error $(n=4)$. of the dietary parameters. The plant foods provide many of the essential compounds, minerals and other compounds that contribute to the enhancement of health. This experiment showed significant increases in nutritional quality of macronutrients and micronutrients as a result of the application of the two forms of zinc (Tables 1 and 2), highlighting the concentration of macronutrients and minerals under the form of sulfate $\mathrm{Zn}$ compared to chelate $\mathrm{Zn}$ (Tables 1 and 2) enhancing the nutritional quality of the elements as $\mathrm{N}, \mathrm{K}, \mathrm{Mg}, \mathrm{Fe}, \mathrm{Zn}$ and $\mathrm{Ni}$.

The doses and $\mathrm{Zn}$ application forms that enhanced the nutritional quality of beans were $\mathrm{Zn}$ Sulfate at doses of 25 to $50 \mu \mathrm{M}$. There are a little researches analyzing the effect of $\mathrm{Zn}$ on the nutritional content of edible plants, after application of this nutrient throughout the growing cycle of the crop. Hermosillo-Cereceres et al. (2013) showed that bean biofortification with selenium showed that the best doses were $40 \mu \mathrm{M}$ selenite and $20 \mu \mathrm{M}$ selenate, as they increased the content of $\mathrm{Zn}$ and antioxidant activity is, as well as improved in seeds bean, which increased the nutritional value of the crop. Furthermore, Yuan et al. (2016) found that the enrichment of $\mathrm{Zn}$ in pea sprouts improved the nutritional quality determined by the content of crude fiber, soluble sugars, protein and $\mathrm{Zn}$ content, indicating that biofortification $\mathrm{Zn}$ improved nutritional quality, as also occurred in this study.

\section{CONCLUSIONS}

Biofortification with Zinc improves antioxidant activity and nutritional quality of beans, considered the main attributes bean quality and consumer health. The highest antioxidant capacity was observed with the dose of $25 \mu \mathrm{M} \mathrm{Zn}$ chelate compared to the form of sulfate; while in the nutritional value of beans both forms of $\mathrm{Zn}$ chelate and sulfate content had similar doses of 25 to $50 \mu \mathrm{M}$. Finally, comment that it is feasible to implement a program biofortification

Table 1: Concentration of macronutrients (\%) in bean seed cv. Strike under different doses of chelate and $\mathrm{Zn}$ sulfate

\begin{tabular}{|c|c|c|c|c|c|}
\hline \multirow[t]{2}{*}{ Doses } & \multicolumn{5}{|c|}{ Concentration of macronutrients (\%) } \\
\hline & $\mathbf{N}$ & $\mathbf{P}$ & K & $\mathrm{Ca}$ & $\mathrm{Mg}$ \\
\hline \multicolumn{6}{|c|}{ Quelato $\mathrm{Zn}(\mu \mathrm{M})$} \\
\hline 0 & $3.09 \pm 0.37$ & $0.13 \pm 0.03$ & $1.56 \pm 0.06$ & $0.023 \pm 0.04$ & $0.07 \pm 0.01$ \\
\hline 25 & $3.44 \pm 0.52$ & $0.19 \pm 0.05$ & $2.07 \pm 0.08$ & $0.052 \pm 0.05$ & $0.17 \pm 0.02$ \\
\hline 50 & $3.64 \pm 0.75$ & $0.21 \pm 0.08$ & $2.06 \pm 0.09$ & $0.038 \pm 0.06$ & $0.15 \pm 0.03$ \\
\hline 100 & $3.47 \pm 0.84$ & $0.14 \pm 0.04$ & $1.93 \pm 0.06$ & $0.040 \pm 0.03$ & $0.16 \pm 0.01$ \\
\hline Significance & * & ns & * & * & ns \\
\hline \multicolumn{6}{|l|}{ Zn sulfate $(\mu \mathrm{M})$} \\
\hline 0 & $3.09 \pm 0.37$ & $0.13 \pm 0.03$ & $1.56 \pm 0.06$ & $0.023 \pm 0.04$ & $0.07 \pm 0.01$ \\
\hline 25 & $3.57 \pm 0.55$ & $0.20 \pm 0.02$ & $2.04 \pm 0.03$ & $0.047 \pm 0.01$ & $0.16 \pm 0.03$ \\
\hline 50 & $3.60 \pm 0.45$ & $0.23 \pm 0.03$ & $1.92 \pm 0.04$ & $0.042 \pm 0.02$ & $0.16 \pm 0.04$ \\
\hline 100 & $3.65 \pm 0.36$ & $0.21 \pm 0.01$ & $2.04 \pm 0.05$ & $0.048 \pm 0.03$ & $0.17 \pm 0.03$ \\
\hline Significance & * & ns & * & * & ns \\
\hline
\end{tabular}

Significance levels presented by: ${ }^{*} \mathrm{P}<0.05,{ }^{* *} \mathrm{P}<0.01,{ }^{* *} \mathrm{P}<0.001$, and $\mathrm{ns}$, not significant. Data are means \pm standard error 
Table 2: Concentration of micronutrients (ppm) in bean seed cv. Strike under different doses of chelate and $\mathrm{Zn}$ sulfate

\begin{tabular}{|c|c|c|c|c|c|}
\hline \multirow[t]{2}{*}{ Doses } & \multicolumn{5}{|c|}{ Concentration of micronutrients (ppm) } \\
\hline & $\mathrm{Fe}$ & Mn & $\mathrm{Zn}$ & $\mathrm{Cu}$ & $\mathbf{N i}$ \\
\hline \multicolumn{6}{|c|}{ Quelate $\mathrm{Zn}(\mu \mathrm{M})$} \\
\hline 0 & $146.5 \pm 0.41$ & $13.9 \pm 0.05$ & $28.4 \pm 1.12$ & $8.01 \pm 0.04$ & $2.63 \pm 0.01$ \\
\hline 25 & $174.4 \pm 1.45$ & $27.5 \pm 0.45$ & $45.7 \pm 2.35$ & $16.26 \pm 0.52$ & $3.67 \pm 0.04$ \\
\hline 50 & $183.7 \pm 2.16$ & $19.0 \pm 0.65$ & $42.8 \pm 3.55$ & $20.67 \pm 0.66$ & $3.49 \pm 0.06$ \\
\hline 100 & $153.0 \pm 1.63$ & $20.9 \pm 0.72$ & $46.3 \pm 3.87$ & $14.97 \pm 0.98$ & $4.14 \pm 0.07$ \\
\hline Significance & * & ns & * & ns & ns \\
\hline \multicolumn{6}{|l|}{ Zn Sulfate $(\mu \mathrm{M})$} \\
\hline 0 & $146.5 \pm 0.41$ & $13.9 \pm 0.05$ & $28.4 \pm 1.12$ & $8.01 \pm 0.04$ & $2.63 \pm 0.01$ \\
\hline 25 & $189.2 \pm 2.89$ & $25.6 \pm 0.98$ & $42.3 \pm 3.11$ & $15.05 \pm 0.74$ & $3.44 \pm 0.05$ \\
\hline 50 & $162.1 \pm 2.03$ & $16.7 \pm 1.12$ & $42.6 \pm 2.87$ & $10.67 \pm 0.63$ & $3.59 \pm 0.06$ \\
\hline 100 & $197.9 \pm 3.45$ & $27.7 \pm 1.82$ & $49.6 \pm 2.54$ & $16.66 \pm 0.81$ & $3.57 \pm 0.08$ \\
\hline Significance & * & ns & * & ns & ns \\
\hline
\end{tabular}

Significance levels presented by: ${ }^{*} \mathrm{P}<0.05,{ }^{* *} \mathrm{P}<0.01$, ${ }^{* *} \mathrm{P}<0.001$, and ns, not significant. Data are means \pm standard error

Zn bean, as this nutrient is more concentrated in the seeds (edible part of the plant), allowing improve its quality and antioxidant capacity.

\section{Author's contributions}

Authors that contributed in this work are presented next. J.P.S.A. and E.S.: Designed and performed research, wrote and enhanced the manuscript. G.D.A.Q.: Contributed to the development of experimental part. M.A.F.C. Contributed in the treatment and data collection. D.L.O.B.: Performed chemical analyses and reviewed all the manuscript. J.M.S.P.: Performed statistical analysis and discussion. All authors approved the final version of the manuscript.

\section{REFERENCES}

Alloway, B. J. 2008. Zinc in Soils and Crop Nutrition, IZA Publications, International Zinc Association, Brussels.

Andreini, C., L. Banci and A. Rosato. 2006. Zinc through the three domains of life. J. Proteome Res. 5: 3173-3178.

Beebe, S., A. V. Gonzalez and J. Rengifo. 2000. Research on trace minerals in the common bean. Food Nutr. Bull. 21(4): 387-391.

Black, R.E., H. A. Lindsy, Z. A. Bhutta, L. E. Caulfield, M. De Onnis, M. Ezzati, C. Mathers and J. Rivera. 2008. Maternal and child under nutrition: Global and regional exposures and health consequences. Lancet. 371: 243-260.

Blair, M. W. 2013. Mineral biofortification strategies for food staples: The example of common bean. J. Agric. Food. Chem. 61: 8287-8294.

Blasco, B., J. J. Ríos, L. M. Cervilla, E. Sánchez-Rodríguez, J. M. Ruíz and L. Romero. 2008. Iodine biofortification and antioxidant capacity of lettuce: Potential benefits for cultivation and human health. Ann. Appl. Biol. 152: 289-299.

Brand-Williams, W., M. E. Cuvelier and C. Berset. 1995. Use of a free radical method to evaluate antioxidant activity. Lebenson. Wiss. Technol. 28: 25-30.

Broadley, M. R., P. J. White, J. P. Hammond, I. Zelko and A. Lux. 2007. Zinc in plants. New Phytol. 173: 677-702.

Cakmak, I. 2000. Role of zinc in protecting plant cells from reactive oxygen species. New Phytol. 146: 185-205.

Cakmak, I. 2008. Enrichment of cereal grains with zinc: Agronomic or genetic biofortification. Plant Soil. 302: 1-17

Hermosillo-Cereceres, M. A., E. Sánchez, A. Guevara-Aguilar, E. Muñoz-Márquez and M. L. García-Bañuelos. 2013. Biofortification and distribution patterns of selenium in bean: Response to selenate a selenite. J. Food Agric. Environ. 11(2): 421-426.

Hoppler, M., I. Egli, N. Petry, D. Gille, C. Zeder, T. Walczyk, M. W. Blair and R. F. Hurrell. 2014. Iron speciation in beans (Phaseolus vulgaris) biofortified by common breeding. J. Food Sci. 79: C1629-C1634.

Hotz, C. and K. M. Brown. 2004. Assessment of the risk of zinc deficiency in populations and options for its control. Food Nutr. Bull. 25: S99-S199.

Jha, A. B., K. Ashokkumar, M. Diapari, S. J. Ambrose, H. Zhang, B. Tar'an, K. E. Betta, A. Vandenberga, T. D. Warkentina and R. W. Purves. 2015. Genetic diversity of folate profiles in seeds of common bean, lentil, chickpea and pea. J. Food Compost. Anal. 42: 134-140.

Johnson, F. and C. Giulivi. 2005. Super oxide dismutases and their impact upon human health. Mol. Aspects Med. 26: 340-352.

Karacan, M. S. and N. Aslantas. 2008. Simultaneous preconcentration and removal of iron, chromium, nickel with $\mathrm{N}, \mathrm{N}^{\prime}$-etylenebis(ethane sulfonamide) ligand on activated carbon in aqueous solution and determination by ICP-OES. J. Hazard. Mater. 155(3): 551-557.

Katoch, R. 2013. Nutritional potential of rice bean (Vigna umbellata): An underutilized legume. J. Food Sci. 78: C8-C16.

Márquez-Quiroz, C., E. De-la-Cruz-Lázaro, R. Osorio-Osorio and E. Sánchez-Chávez. 2015. Biofortification of cowpea beans with iron: Iron' s influence on mineral content and yield. J. Soil Sci. Plant Nutr. 15(4): 839-847.

Mates, J. M., C. Pérez-Gómez and I. Núñez de Castro. 1999. Antioxidant enzymes and human diseases. Clin. Biochem. 32: 595-603.

Manzeke, G. M., F. Mtambanengwe, H. Nezomba and P. Mapfumo. 2014. Zinc fertilization influence on maize productivity and grain nutritional quality under integrated soil fertility management in Zimbabwe. Field Crop Res. 166: 128-136.

Mao, H., J. Wang, Z. Wang, Y. Zan, G. Lyons and C. Zou. 2014 Using agronomic biofortification to boost zinc, selenium, and iodine concentrations of food crops grown on the loess plateau in China. J. Soil Sci. Plant Nutr. 14: 459-470.

Padilla, F. C., A. M. Rincón and L. Bou-Rached. 2008. Contenido de polifenoles y actividad antioxidante de varias semillas y nueces. 
Arch. Latinoam. Nutr. 58: 303-308.

Prasad, R., Y. S. Shivay and D. Kumar. 2014. Agronomic biofortification of cereal grains with iron and zinc. Adv. Agron. 125: 55-91.

Raymond, F. and M. D. Burk. 2002. Selenium, an antioxidant nutrient. Nutr. Clin. Care. 5(2): 75-79.

Ríos, J. J., M. A. Rosales, B. Blasco, L. M. Cervilla, L. Romero and J. M. Ruiz. 2008. Biofortification of Se and induction of the antioxidant capacity in lettuce plants. Sci. Hortic. 116: 248-255.

Sadeghzadeh, B and Z. Rengel. 2013. A review of zinc nutrition and plant breeding. J. Soil Sci. Plant Nutr. 13: 905-927.

Shivay, Y. S., D. Kumar and R. Prasad. 2008. Effect of zinc-enriched urea on productivity, zinc uptake and efficiency of an aromatic rice-wheat cropping system. Nutr. Cycling Agroecosystem. 81: 229-243.

Sida-Arreola, J. P., E. Sánchez-Chávez, G. D. Ávila-Quezada, P. B. Zamudio-Flores and C. H. Acosta Muñiz. 2015. Iron biofortification and its impact on antioxidant system, yield, and biomass in common bean. Plant Soil Environ. 61(12): 573-576.

Storksdieck, S. and R. F. Hurrell. 2009. The impacts of trace elements from plants on human nutrition: A case for biofortification. In: Buñuelos, G. S and Z. Q. Lin (Ed.), Biofortified Agricultural Products, CRC Press, Boca Raton, FL.

Wolf, B. 1982. A comprehensive system of leaf analysis and its use for diagnosis crop nutrients status. Commun. Soil Sci. Plant Anal. 13: 1035-1059.

Yuan, L., J. Wu, C. Wang, S. Liu and S. Zhu. 2016. Effect of zinc enrichment on growth and nutritional quality in pea sprouts. J. Food Nutr. Res. 4(2): 100-107.

Zhu, C., G. Sanahuja, D. Yuan, G. Farre, G. Arjo, J. Berman, U. Zorrilla-López, R. Banakar, C. Bai, E. Pérez-Massot, L. Bassie, T. Capell and P. Christou. 2013. Biofortification of plants with altered antioxidant content and composition: Genetic ingineering strategies. Plant Biotechnol. J. 11: 129-141. 